\title{
The effect of enzyme preparations and lecithin on the blood picture of laying hens
}

\author{
B.S. Kaloev*, V.V. Nogaeva, F.M. Kulova, Z.A. Kadzayeva, L.H. \\ Albegova
}

1Gorsky State Agrarian University, 362040, Russian Federation, Vladikavkaz, 37 Kirov Street

*Corresponding Author E-mail: bkaloev@yandex.ru

Journal of Livestock Science (ISSN online 2277-6214) 13: 1-5

Received on 1/9/21; Accepted on 15/12/21; Published on 3/1/22

doi. 10.33259/JLivestSci.2022.1-5

\begin{abstract}
The use of new feed factors in poultry feeding is necessarily reflected in the change in blood parameters. The article presents the results of physiological studies on the study of changes in the hematological parameters of laying hens with the additional use of enzyme preparations Sanzaym and Sanfayz 5000, as well as lecithin in their feeding. Scientific and economic experience, during which the main physiological indicators were studied, was carried out in the State Unitary Enterprise of the Breeding Reproductor "Urus-Martanovsky" of the Chechen Republic on laying hens of the Loman Brown breed. As the main diet in the experiment, compound feed was used, prepared on the basis of corn, barley, wheat, sunflower meal. It was fed to a bird of the control group. In addition to the main diet, the livestock of the 1 experimental group were additionally fed two enzyme preparations: Sanzaym $(100 \mathrm{~g} / \mathrm{t}$ of feed) and Sanfayz 5000 (80 g/t of feed). Phospholipid lecithin, in the amount of $10 \mathrm{~g} / \mathrm{kg}$ of feed, was fed to livestock. The use of enzyme preparations and lecithin increased egg production per average carrier by 24.5 pcs or $8.9 \%$, the intensity of egg production by $7.42 \%$, which made it possible to obtain $245.4 \mathrm{~kg}$ or $14.6 \% \mathrm{more}$ egg mass than the control group.
\end{abstract}

Key words: enzymes; lecithin; laying hens; hematological parameters. 


\section{Introduction}

The active use of various biologically active preparations in feeding farm animals and poultry is based on the possibility of increasing the digestibility and use of nutrients in the diet, improving metabolic processes in the body, reducing feed consumption, which has a positive effect on the quality and quantity of animal products received. Among these drugs are well established enzyme preparations (Anchikov \& Kislyuk, 1999; Kuzmin, 2004; Egorov \& Egorov 2009; Baeva et al., 2011; Maltsev \& Amiranashvili, 2011; Nogayeva et al., 2016; Kaloev \& Ibragimov, 2018; Ibragimov\& Kaloev, 2018) and phospholipids (Yanovich\& Lagodyuk, 1991; Chikov \& Skvortsova, 2010; Aydinian, 2015; Shabanov et al., 2019; Kaloev et al., 2020.). The feeding of probiotics and enzymes like lecithin was found to be useful in poultry production (Temiraev et al 2020 and Kaloev et al 2020)

However, it should be borne in mind that high productivity indicators of farm animals and poultry provide for the intensification of metabolic processes in the body, which affect the biochemical status of blood. Blood, due to its buffering properties, quickly reacts, by changing its indicators, to the impact of various feed factors, which are one of the main external factors affecting the blood picture of animals and poultry. Significant deviations of hematological parameters beyond the appropriate physiological framework can serve as an indicator of the negative effect of the feed factor on homeostasis. The published results of physiological studies of poultry allow us to state the positive effect of biologically active drugs introduced into the diet on the hematological parameters of the experimental livestock (Tmenov \& Vanieva, 2014; Kaloev \& Chertkoev, 2017; Kaloev \& Ibragimov, 2017).

Based on the above, the purpose of the conducted physiological studies was to study the effect of enzyme preparations and lecithin introduced into the diet of laying hens on blood parameters. To achieve this goal, the task was to determine the main morphological and biochemical parameters of the blood of laying hens in experimental groups and compare them with each other.

\section{Materials and Methods}

The planned physiological studies were carried out within the framework of scientific and production experience to study the effectiveness of the use of enzyme preparations Sanzaym and Sanfayz 5000, as well as lecithin in the cultivation of laying hens of the Loman Brown breed in the conditions of the State Unitary Enterprise poultry farm "Urus-Martanovskaya" of the Chechen Republic (Latitude: $43^{\circ} 11.3982$ 's. w. Longitude: $45^{\circ} 17.0238^{\prime}$ w. d.), according to the scheme presented in Table 1.

The research and production experience was conducted from 4 to 15 months of age of laying hens, which were divided into 4 groups: one control and three experimental ones, 100 heads each. Mixed feed was prepared in the feed shop of the farm itself from locally produced cereals-corn, wheat and barley with the addition of sunflower meal. Enzyme preparations Sanzaym and Sanfayz 5000 are developed by specialists of the Chinese firm "Wuhan Sunhy Biology Co., Ltd" and are made by LLC "Company Agros" Yekaterinburg.

Within the framework of the experiment, a complex of physiological studies was conducted. To study the hematological parameters, at the end of the experiment, 5 heads from each group of laying hens were taken from the axillary vein in the morning, before feeding, and blood was stabilized with heparin. To separate the serum, the blood was centrifuged at 2000-3000 rpm. The following indicators were studied in the blood according to the methods described by I. P. Kondrakhin (1985): red blood cells and white blood cells - by counting in the Goryaev chamber; hemoglobin - according to the Sali method in the hemometer; total protein-refractometrically by the RLU device; protein fractions-by electrophoresis on paper; total lipids - according to Folch; calcium-according to De Waard; phosphorus-according to Yudelevich; sugar-according to the method of M. J. Sommoqqi. The glucose content in the blood serum was determined by the glucosidase method, and the content of triglycerides and cholesterol was determined by the enzymatic method.

Table 1-Scheme of scientific and production experience

\begin{tabular}{|l|l|}
\hline Group & Features of feeding the experimental bird \\
\hline Control & $\begin{array}{l}\text { Full-fledged compound feeds based on corn, barley, wheat, } \\
\text { sunflower cake or meal (OR-the main diet) }\end{array}$ \\
\hline I & $\begin{array}{l}\text { OR + enzyme preparation Sanzaym at the rate of } 100 \mathrm{~g} / \mathrm{t} \text { of } \\
\text { feed }+ \text { enzyme preparation Sanfayz } 5000 \text { at the rate of } 80 \mathrm{~g} / \mathrm{t} \\
\text { of feed }\end{array}$ \\
\hline II & $\begin{array}{l}\text { OR + lecithin, at the rate of } 10 \mathrm{~g} / \mathrm{kg} \text { of feed } \\
\text { feed }+ \text { enzyme preparation Sanfayz } 5000, \text { at the rate of } 80 \mathrm{~g} / \mathrm{t} \\
\text { of feed }+ \text { lecithin, at the rate of } 10 \mathrm{~g} / \mathrm{kg} \text { of feed }\end{array}$ \\
\hline III
\end{tabular}




\section{Results and discussion}

Changes in the productive indicators of egg-bearing birds are reflected in the biochemical status of blood in their body. Moreover, if these changes are associated with the intensification of metabolic processes, due to the involvement of biologically active drugs in them. Based on this, the main morphological parameters of blood in laying hens were studied. They are shown in table 2.

These data indicate that the use of the claimed enzyme preparations and lecithin to a certain extent changed the morphological parameters of the blood of laying hens of the experimental groups, compared with analogues from the control group. These changes primarily affected red blood cells and hemoglobin, since the increase in their number recorded in all experimental groups was statistically significant. Further, we can note a stronger influence on these indicators of the desired enzyme preparations than the separate use of lecithin. However, it is necessary to recognize the probability of synergism of the interaction of enzyme preparations and lecithin, which is confirmed by the obtained maximum indicators. In particular, in laying hens, feeding the enzyme preparations Sanzaym and Sanfayz 5000, together with lecithin (experimental group 3), contributed to a significant increase in the content of red blood cells by $0.35 \times 1012 /$, and hemoglobin - by $3.60 \mathrm{~g} / \mathrm{l}$, respectively, compared with the control group. This circumstance can be explained by the maximum intensification of metabolic processes in the bird's body and the need for more intensive transport of oxygen and nutrients.

It can also be noted that there were no significant, and even more significant, differences between the groups in terms of the content of white blood cells, which is evidence that the inclusion of biologically active preparations studied in the diet of laying hens did not negatively affect the homeostasis of the body in any way. It is known that the change in productive indicators is a consequence of changes in protein metabolism, which can be characterized by the content of total protein in the blood and the distribution of its fractions (Table 3 ).

The maximum effect on the protein content in the blood was provided by the joint inclusion of both enzyme preparations and lecithin in the poultry diet. At the same time, the total protein content in the blood of laying hens increased from 52.64 to $56.03 \mathrm{~g} / \mathrm{l}$. With the separate use of enzyme preparations and lecithin, there is also a significant superiority of the experimental groups over the control group, according to this indicator, but to a lesser extent.

An important indicator of protein metabolism is the ratio of protein fractions in the blood. Intensive protein metabolism in laying hens probably caused a significant effect of enzyme preparations and lecithin on the concentration of total protein and its fractions in the blood. In particular, a significant increase in protein in the blood of poultry was recorded in all experimental groups. It is noticeable that this increase is accompanied by a simultaneous decrease in the relative content of albumins and an increase in the relative content of globulins, both in general and for individual fractions. In the blood of chickens of the 1st experimental group (with enzyme preparations in the diet), there is a significant increase in the concentration of $\alpha$ - and $\gamma$-globulins, in the blood of chickens of the 2 nd experimental group (with lecithin in the diet) - only $\gamma$-globulins. In the blood of chickens of the 3 experimental group (with enzyme preparations and lecithin in the diet), not only a significant increase in the concentration of $\alpha$ - and $\gamma$ - globulins was recorded, but also a significant decrease in the concentration of $\beta$ globulins. The metabolism and its changes in the bird's body can also be characterized by biochemical blood parameters, some of which are shown in Table 4.

The main indicator of carbohydrate metabolism, which characterizes the intensity of metabolic processes, is the glucose content in the blood serum, showing the difference between its formation and use in tissues. Increased metabolism requires increased formation and glucose content in the body, as the main energy material of cells. Upon a detailed review of the results obtained, it can be noted that in all experimental groups, compared with the control, there was a significant increase in the concentration of glucose in the blood serum, which is consistent with the results of previous physiological and zootechnical studies. The maximum difference is noticeable between the control and 3 experimental groups, which is $0.87 \mathrm{mmol} / \mathrm{l}$ and $17.5 \%$ - in laying hens. It can also be stated that the results obtained in the course of these studies corresponded to the normative values characteristic of adult chickens.

Important indicators that characterize the egg production of chickens are the content of triglycerides and cholesterol in the blood serum. Their accumulation in the blood, in increased amounts, can serve as an indicator of the low efficiency of the use of feed nutrients and, in particular, fats. At the same time, their sharp reduction can be an indicator of liver atrophy, acute poisoning, and a general violation of the functional activity of the body.

In our case, there were no significant differences between the groups in the content of triglycerides in the blood serum as a result of feeding the studied biologically active drugs, although a tendency to decrease them was observed in the experimental groups. At the same time, the data given in Table 4 allow us to note a significant decrease in the cholesterol content in the blood serum of experimental birds, due to the additional inclusion of lecithin in their diet separately ( 2 experimental group) to $3.967 \mathrm{mmol} / \mathrm{l}$ and together with enzyme preparations (3 experimental group), respectively, to $3.843 \mathrm{mmol} / \mathrm{l}$.

The content of calcium and phosphorus in the blood serum reflects the level and course of mineral metabolism in the bird's body. The analysis of the obtained data suggests that the desired enzyme preparations had a significant positive effect on the calcium content in the blood serum, increasing its amount by $0.35 \mathrm{mmol} / \mathrm{l}$ in layers. The use of lecithin alone had a less significant effect. The increase in the calcium content in the blood serum compared to the control in laying hens was $0.27 \mathrm{mmol} / \mathrm{l}$. When using enzyme preparations and lecithin together, the 
Table 2 - Morphological parameters of blood

\begin{tabular}{|l|l|l|l|}
\hline \multirow{2}{*}{ Group } & Indicators & \multicolumn{3}{|l|}{} \\
\cline { 2 - 4 } & Red blood cells, 1012/1 & White blood cells, 109/1 & Hemoglobin, g / \\
\hline Control & $3.71 \pm 0.10$ & $40.38 \pm 0.48$ & $78.72 \pm 1.02$ \\
\hline I & $4.03 \pm 0.10^{*}$ & $40.20 \pm 0.32$ & $82.26 \pm 1.22^{*}$ \\
\hline II & $3.95 \pm 0.12^{*}$ & $40.31 \pm 0.35$ & $81.87 \pm 1.16^{*}$ \\
\hline III & $4.06 \pm 0.14^{*}$ & $40.18 \pm 0.50$ & $82.32 \pm 1.06^{*}$ \\
\hline \multicolumn{3}{|c}{$*_{-} \mathrm{p} \geq 0.95$} &
\end{tabular}

Table 3-Protein content and its fractions in the blood of the experimental birds, $(n=5)$

\begin{tabular}{|l|l|l|l|l|l|}
\hline Group & Total protein, g/l & \multirow{2}{*}{ Albumins, $\%$} & \multicolumn{3}{|c|}{ Globulins, \% } \\
\cline { 3 - 6 } & & & $\alpha-$ & $\beta-$ & $\gamma-$ \\
\hline Control & $52.64 \pm 0.56$ & $34.91 \pm 0.34$ & $17.92 \pm 0.15$ & $14.35 \pm 0.23$ & $32.82 \pm 0.36$ \\
\hline I & $55.72 \pm 0.60^{*}$ & $33.10 \pm 0.28^{*}$ & $18.48 \pm 0.17^{*}$ & $13.99 \pm 0.19$ & $34.47 \pm 0.34^{*}$ \\
\hline II & $54.67 \pm 0.41^{*}$ & $33.42 \pm 0.35^{*}$ & $18.24 \pm 0.16$ & $14.18 \pm 0.25$ & $34.16 \pm 0.40^{*}$ \\
\hline III & $56.03 \pm 0.65^{*}$ & $33.01 \pm 0.40^{*}$ & $18.51 \pm 0.13^{*}$ & $13.70 \pm 0.20^{*}$ & $34.78 \pm 0.45^{*}$ \\
\hline
\end{tabular}

Table 4- Biochemical parameters of the blood serum of the experimental birds, $\mathrm{mmol} / \mathrm{l}(\mathrm{n}=5)$

\begin{tabular}{|l|l|l|l|l|l|}
\hline \multirow{2}{*}{ Group } & It is contained in the blood serum \\
\cline { 2 - 6 } & glucose & triglycerides & cholesterol & total calcium & inorganic phosphorus \\
\hline Control & $4.96 \pm 0.12$ & $0.755 \pm 0.04$ & $4.334 \pm 0.10$ & $4.04 \pm 0.08$ & $1.74 \pm 0.07$ \\
\hline I & $5.71 \pm 0.14^{*}$ & $0.742 \pm 0.05$ & $4.212 \pm 0.13$ & $4.39 \pm 0.10^{*}$ & $1.98 \pm 0.06^{*}$ \\
\hline II & $5.58 \pm 0.10^{*}$ & $0.729 \pm 0.05$ & $3.967 \pm 0.10^{*}$ & $4.31 \pm 0.06^{*}$ & $1.94 \pm 0.05^{*}$ \\
\hline III & $5.83 \pm 0.19^{*}$ & $0.714 \pm 0.06$ & $3.843 \pm 0.12^{*}$ & $4.42 \pm 0.09^{*}$ & $2.02 \pm 0.07^{*}$ \\
\hline
\end{tabular}

concentration of calcium in the blood of poultry of the 3 experimental group was $4.42 \mathrm{mmol} / \mathrm{l}$, which exceeds the indicator of the control group by $9.4 \%$.

The fact that among the biologically active drugs we are studying there are Sanfayz 5000, based on phytase and lecithin, which is a phospholipid, caused a more active effect on phosphorus metabolism and, accordingly, affected its concentration in the blood.

The importance of studying the content of inorganic phosphorus in the blood serum is also confirmed by the fact that it determines the content and effectiveness of the use of phospholipids in the poultry body. The concentration of inorganic phosphorus significantly increased in all experimental groups, but especially in the 3rd experimental group with the joint inclusion of both enzyme preparations and lecithin in the poultry diet. In laying hens, the increase in the concentration of phosphorus in the blood serum was $0.28 \mathrm{mmol} / \mathrm{l}$, which is evidence of the intensification of phosphorus metabolism under the action of biologically active drugs used.

The increase in productive indicators is the result of an improvement in metabolism, which is reflected in the blood picture of the experimental livestock (Tmenov \& Vanieva, 2014; Kaloev \& Chertkoev, 2017). In particular, the improvement of protein metabolism in our studies affected the protein content in the blood and the distribution of its fractions. A significant improvement in protein metabolism can be noted in the livestock of laying hens that received both enzyme preparations together, as well as lecithin.

To confirm the improvement of carbohydrate metabolism, we can cite data on the blood glucose content of laying hens of the 3 experimental group $-5.75 \mathrm{mmol} / \mathrm{l}$, which significantly exceeded the indicators of the control group $-5.14 \mathrm{mmol} / \mathrm{l}$. The improvement of mineral metabolism due to the use of enzyme preparations in poultry feeding is confirmed by the indicators of the content of calcium and phosphorus in the blood serum of poultry of the experimental groups. The analysis of the obtained data suggests that the content of calcium and phosphorus of the desired enzyme preparations had a certain positive effect, which was expressed in an increase in their concentration in the blood serum compared to the control.

Conclusion. After analyzing the morphological and biochemical parameters of blood studied during physiological studies, we can draw the following conclusions:

1. All hematological parameters studied in the course of the conducted studies correspond to the existing physiological norms for adult chickens.

2. The use of the studied biologically active preparations in the feeding of experimental poultry has a stable tendency to significantly improve the main morphological and biochemical parameters of blood. 
3. The greatest positive effect on the effect on hematological parameters was recorded when the enzyme preparations Sanzaym and Sanfayz 5000 were included in the diet of the experimental bird in an amount of $100 \mathrm{~g} / \mathrm{t}$ of mixed feed, as well as lecithin, in an amount of $10 \mathrm{~g} / \mathrm{kg}$ of mixed feed.

Acknowledgements The authors express their gratitude to the State Unitary Enterprise Breeding Reproducer " Urus-Martanovsky " of the Chechen Republic for the opportunity to conduct research on laying hens.

Conflict of interest declaration Authors declare there are no conflicts of interests.

\section{References}

1) Anchikov V, Kislyuk S, 1999. The effectiveness of the use of enzymes in poultry farming. Compound feed. 2 : 30-31

2) Aydinyan GT, 2015.The effect of the combined use of lecithin and L-carnitine in mixed feeds of broiler chickens with a reduced level of metabolic energy. Animal science 9: 20-22.

3) Baeva AA, Tletseruk IR, Dzidzoeva ZG, 2011. The effect of enzyme preparations on productivity and metabolism in broiler chickens. Bulletin of the Maikop State Technological University 3: 30-33.

4) Chikov AE, Skvortsova LN, 2010. The role of phospholipids of vegetable oils in broiler feeding. Poultry farming 3: 23-24.

5) Egorov I, Egorov A, 2009. The role of enzyme preparations in improving the efficiency of compound feeds containing difficult-to-hydrolyze components. Poultry farming 4: 16-38.

6) Ibragimov MO, Kaloev BS, 2018. Conversion of feed when using enzyme preparations in the diet. Izvestiya FGBOU VPO "Gorsky GAU" 55 (2): 91-96

7) Kaloev BS, Chertkoev GB, 2017. The effect of dry bard in combination with the enzyme preparation "Feedbest VGPro" on the digestibility and use of nutrients by broiler chickens. Perm Agrarian Bulletin. Perm 3(19): 135-140.

8) Kaloev BS, Ibragimov MO, 2017. Changes in the biochemical parameters of broiler blood when using enzyme preparations in their diets. Internauka: scientific Journal 2(6) : 52-53

9) Kaloev BS, Ibragimov MO, 2018. Egg-laying hens that received enzyme preparations with feed. Poultry farming 5: 36-40.

10) Kondrakhin IP, Kurilov HB, Malakhov AG, 1985. Clinical laboratory diagnostics in veterinary medicine: reference publication. Moscow. Agro-industrial publishing house: 287.

11) Kuzmina V, 2004. Enzymes is an integral part of diets. Feed 3: 70-71.

12) Maltseva NA, Amiranashvili EI, 2011. Enzyme preparations of Sansim and Canvas in feeding laying hens. Materials of the 12th Ukrainian Conference on Poultry Farming with international participation. Kharkiv 190-195.

13) Nogaeva VV, Kaloev BS, Kulova FM, Kadzaeva ZA, 2016. The use of the feed additive "MFEED" in feeding broiler chickens. In the collection: Achievements of science - agriculture, materials of the scientific and practical conference 70-74.

14) Shabanov MO, Baeva ZT, Gadzaonov RH, Tsugkieva VB, Dzagurov BA, Kesaev HE, Kokov TN, 2019. Influence of adsorbent and preparation of lecithin on the scar metabolism and chemical composition of the liver feedlot steers in violation of the ecology of their power. Proceedings of the Gorsky State Agrarian University 56(4): 113-119.

15) Tmenov ID, Vanieva BB, 2014. The results of the effect of the additive Hydrolaktiv and MEK-CX-3 on the hematological parameters of broiler chickens. Proceedings of the Gorsky State Agrarian University 51(1): 54-58.

16) Temiraev VH, Baeva AA, Vityuk LA, Mamukaev MN, Yurina NA, Ktsoeva II, Bobyleva LA, Zagaraeva EF, Kokov TN, Vologirova FA 2020. Effect of probiotics on digestive metabolism in growing and laying poultry birds. Journal of Livestock Science 11: 33-39. doi. 10.33259/JLivestSci.2020.33-39

17) Yanovich VG, Lagodyuk PZ, 1991. Lipid Metabolism in animals in ontogenesis. Agropromizdat 317. 